\title{
Lives of Brothel Based Sex Workers in Khulna, Bangladesh
}

\author{
Quazi Zahangir Hossain ${ }^{1}$, Qazi Azad-uz-zaman ${ }^{2, *}$, Swapan Kumar Roy ${ }^{3}$ \\ ${ }^{1}$ Environmental Science Discipline, Life Science School, Khulna University, Bangladesh \\ ${ }^{2}$ Japan Association of Drainage and Environment (JADE), Bangladesh \\ ${ }^{3}$ Department of Livestock Services, Batiaghata Upazila, Khulna, Bangladesh \\ *Corresponding Author: aazad013@yahoo.com
}

\begin{abstract}
Bangladesh is a Muslim dominated country in south Asia where sex trade is mainly illegal but open secret. Only few workers have license and provide service in registered brothels. Banisanta brothel is one of the registered bawdyhouses in Khulna where 110 sex-workers were living in 2014. They entered into the profession because of a variety of socio-economic reasons. The factors of entering women into sex work in Banisanta brothel were observed by cross sectional study in July 2014. The sex-workers were mainly illiterate, aged range between 25-35 years, from rural areas, as well as landless families. About half of them entered the profession willingly because of low family income. Some other reasons identified by survey were being cheated, sold to the brothel and forced. More than half had experience with other labour market before sex work but left job because of harassment, poor income coupled with physical assault and sexual abuse, as well as poor working condition. Majority was aware of STI/STD as a result of receiving counselling, advice to use condom and other health related services from different organizations. Although drinking water was not enough and hard to collect, as well as using unhygienic latrine mainly, they were not suffering frequently from water borne diseases like diarrhoea, dysentery or jaundice.
\end{abstract}

Keywords Brothel, Sex Worker, Entering Factors, Living Condition, STI/STD

\section{Introduction}

Sex work is exchange of sexual services, performances, or a product for material compensation which includes activities of direct physical contact between buyers and sellers as well as indirect sexual stimulation (Routledge, 2000) emphasizing labour and economic implications. Some prefer the use of the term because it seemingly grants more agencies to the sellers of these services. Prostitution is the business or practice of providing sexual services to another person in return for payment. Prostitution is commonly defined as a custom of having sexual relations in exchange for economic gain (Wood, 2001). The person receiving payment for sexual services is called a prostitute or sex worker. Prostitution is sometimes referred to as "the world's oldest profession".

Bangladesh is a third-world Muslim dominated country with a deadly combination of dire poverty and a conservative society that holds many double standards. Here religion plays a pivotal role in shaping not only the socio-sexual morality, but also determining politics. The religious backdrop makes prostitution, child abuse and sexuality related to a big concern in our society. The country has more than 100,000 women in the sex trade (ATSEC, 1998). In Bangladesh there are about 14 acknowledged brothels. Among them seven are located in Dhaka division, Six in Khulna division and only one, Patuakhali brothel in Barisal division. The brothels are generally located in or near the town, commercial area or river port (Alam, 2005). Banisanta $\left(22^{\circ} 27^{\prime} 31^{\prime \prime} \mathrm{N} 89^{\circ} 35^{\prime} 2^{\prime \prime} \mathrm{E}\right)$ is located at Dacope upazila of Khulna district under Khulna division where 110 women are living. It was established in the Mongla sea port, along with the port in 1950. The dockworkers and sailors are the main clients of the brothel (Tahmina \& Moral, 2004). Banisanta is called the sad destiny of those women who are now ruined by the climate change and shunned by society (Gomes, 2014). Phultala brothel is located near of the bazaar under Phultala upazila of Khulna district. About 90 sex workers were living to the brothels (SWNB, 2001).

Exploring the household composition of female sex-workers in Daulatdia brothel, under Rajbari district of Bangladesh assumed that the oppressive patriarchal brothel framework, they exercise power and agency at the level of household in terms of economic independence, motherhood, social mobility, household organization and the struggle for respectability (Karim, 2004).

A recent study on experiencing vulnerability, abuse and deception in Sylhet city of Bangladesh enter into prostitution 
revealed that no prostitutes had prior idea regarding professional sex work but they had to enter into this profession for many reasons such as financial crisis, poverty, lack of job facilities, deception by lovers, husbands, brokers, desertion, divorce, physical and/or emotional and sexual abuse. In addition to this, social stigma, gender based discriminatory attitude and outlook of the male dominated society discouraged the women to leave their profession. Overall, our findings reflect the complex interrelationships between both the push and pull factors that generally keep the women and girls entrapped into prostitution in the context of Bangladesh (Alam \& Das, 2014).

The prostitution is in its peak in sub-continent like India and Pakistan. Sex work in India is planned and done in secret (Dandona et al., 2006). India has more than 100,000 prostitutes in the only six metropolitan cities: Mumbai, Kolkata, Chennai, Delhi, Hyderabad and Bangalore (ECPAT, 2005). After partition in 1947, Pakistan inherited the historical red-light districts in Lahore, Faisalabad, Rawalpindi, Karachi and Multan. It is estimated that there are approximately 26,000 women selling sex, who are living and working in four concentrated areas of Lahore (WB, 2006). Prostitution in Pakistan is a taboo culture of sex-trade that exists as an open secret but illegal. Culture and traditions do not allow the exposure of such profession. ANLAAP said that Karachi is notorious for receiving a million Bangladeshi and more than 200,000 Burmese prostitute women (Naqvi \& Jerar, 2005). National arrest estimates from 2009 reported that out of 36,605 adults arrested for prostitution, approximately $70 \%$ were female and $30 \%$ male (FBI, 2009, 2010). Extrapolation of surveillance data indicates that there are around 136,300 female sex workers (FSWs) nationwide. They are often initiated into sex work at an early age of 21 for FSWs. Sex work is often the main livelihood for sex workers and monthly income ranged from Rs 3,000 to Rs 12,000 for FSWs (Khan \& Khan, 2005). Once a woman introduces herself to the sex industry, she is unable to return to her native place (Frederick, 2000). FSWs in eight cities estimated that there were about 34,500 FSWs in these cities, ranging from 760 in Quetta to 14,150 in Lahore. Overall, about $58 \%$ of FSWs worked out of the homes, over $40 \%$ worked in public places and only $2 \%$ worked out of brothels (Blanchard et al., 2008). Evidences indicate that prostitution widely and rapidly emerging profession and prostitutes are existed in all major regions of the world. ILO estimates that over 1.8 million youth all over the world are involved in occupation of prostitution. $79 \%$ of 8000 prostitutes were working as off-street prostitutes (i.e. those working in flats, massage parlours and small building) in London (Dickson, 2004).

Many studies throughout the world have identified diverse factors causing female prostitution. Women and girls are often forced into prostitution through kidnapping, abduction and cheating. The research aims to investigate the reasons of entering into sex work and their living conditions in brothels.

\section{Materials and Methods}

Mixed method was applied for data collection.

Questionnaire survey was conducted in July, 2014 at Banisanta brothel of Dacope upazila under Khulna district. A Focus Group Discussion (FGD) was conducted at Phultala brothel of Khulna city in April 2015.

\section{Sample Size Determination}

The numbers of respondents were 51 out of 110 sex-workers living. The size of the sample was calculated using below mentioned formula (for the finite population) as New $\mathrm{SS}=\mathrm{SS} /\{1+(\mathrm{SS}-1) / \mathrm{Pop}\}$

Here, $\mathrm{SS}=$ Sample size; $\mathrm{Z}=$ given $\mathrm{z}$-value; $\mathrm{p}=$ Percentage of population; $\mathrm{C}=$ Confidence level $(10 \%) ; \mathrm{Pop}=$ Population.

\section{Sampling Technique}

The respondents were selected through systematic sampling technique and were confidentially interviewed face to face using a semi-structured questionnaire.

\section{Data Collection}

The study required different types of information from the sex-workers. Informed consent was obtained from each participant verbally prior to the beginning of survey. The respondents were requested to provide relevant information from their understanding and experience and were filled up a semi-structured questionnaire in front of them. They were not compelled to answer all of the questions. They even had right to withdraw after response. They were assured that the information from them to be used for specific research only with due confidentiality. During data collection, the data collectors were asked strictly to avoid keeping mobile phone and camera with them. They were also asked to behave politely with due respect. So there was no chance of physical, social, and psychological risk for the respondent as well as invasion to them and their privacy. We avoided the topics carefully that can create any discomfort to them.

A group of MPH students of Northern University Bangladesh were engaged in data collection from the field. Before going to field work, the correspondents were trained properly by the research team. Before using the questionnaire, it had been pre-tested to other areas. Necessary adjustments were done from feedback of pre-test.

Twelve sex workers were participated to our discussion. Informed consent was taken from every respondent previously. Main points of their discussion were noted following a predesigned FGD guide. This discussion was being held mainly to compare and validate the result obtained from Banisanta brothel.

\section{Data Analysis}

Simple descriptive statistical analysis was done by SPSS (version 16.0) to meet the objective of the study. 


\section{Results}

Results found from the survey are being shown distributing into different sub-sectors like socio-economic; drinking water and sanitation; health facilities; disease condition; and finally the causes of entering into sex work.

\section{Socio-economic Condition}

Table 1 shows the socio-economic condition of the sex workers. About $85 \%$ of the sex workers were from age between 20 to 40 years and only one person was found less than 20 years of age. More than three-fifth (65\%) of them were illiterate and only $33 \%$ had primary education. One person was found having secondary schooling. About $96 \%$ of them were from Muslim community. The houses they had been living during survey was mainly rental (71\%) but some of them had their own house $(29 \%)$. About $60 \%$ of the houses had electricity connection. Around $45 \%$ of the sex workers came to the brothel from rural areas and the remaining 55\% from sub-urban $(33 \%)$ and urban areas $(22 \%)$. Figure 1 shows the distribution of income depending on age. The regression in figure 1 shows a reversal relationship between income and age.

Table 1. Socio-economic condition of the sex workers

\begin{tabular}{|c|c|c|}
\hline Variables & Frequency & Percentage \\
\hline \multicolumn{3}{|l|}{ Age } \\
\hline$<20$ & 1 & 2 \\
\hline $20-25$ & 9 & 18 \\
\hline $25-30$ & 13 & 25 \\
\hline $30-35$ & 12 & 24 \\
\hline $35-40$ & 9 & 18 \\
\hline $40-45$ & 3 & 6 \\
\hline $45-50$ & 3 & 6 \\
\hline$\geq 50$ & 1 & 2 \\
\hline \multicolumn{3}{|l|}{ Education } \\
\hline No schooling & 33 & 65 \\
\hline Primary schooling & 17 & 33 \\
\hline Schooling up to class seven & 0 & 0 \\
\hline Schooling up to class ten & 1 & 2 \\
\hline \multicolumn{3}{|l|}{ Religion } \\
\hline Hindu & 2 & 4 \\
\hline Muslim & 49 & 96 \\
\hline \multicolumn{3}{|c|}{ Types of residence } \\
\hline Own house & 15 & 29 \\
\hline Rental house & 36 & 71 \\
\hline \multicolumn{3}{|c|}{ Consuming electricity } \\
\hline Yes & 21 & 41 \\
\hline No & 30 & 59 \\
\hline \multicolumn{3}{|l|}{ Previous residence } \\
\hline Rural & 23 & 45 \\
\hline Sub-urban & 17 & 33 \\
\hline Urban & 11 & 22 \\
\hline \multicolumn{3}{|c|}{ Main occupation of your parent's family } \\
\hline Farming & 17 & 33 \\
\hline Business: $\mathrm{BDT}>30000$ & 2 & 4 \\
\hline Business: BDT $<30000$ & 1 & 2 \\
\hline Day labour & 21 & 41 \\
\hline Others & 10 & 20 \\
\hline
\end{tabular}

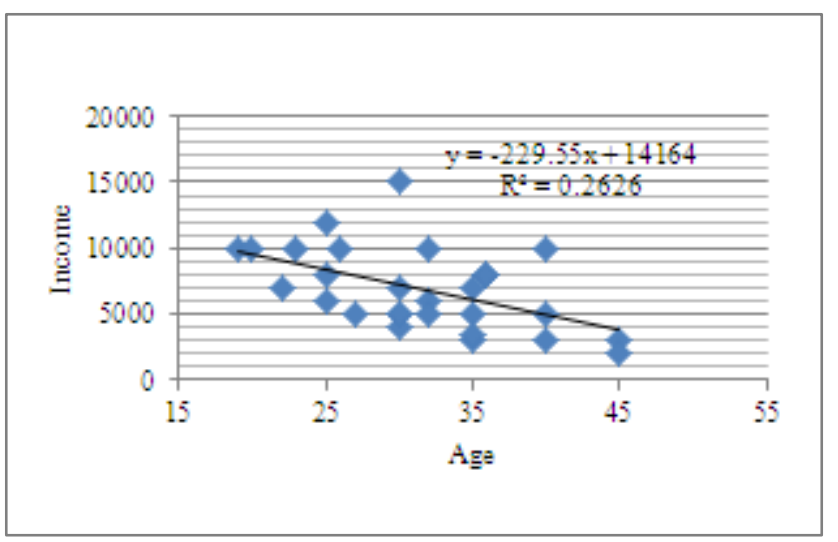

Figure 1. Scatter diagram of income depending on age

FGD in Phultala brothel does not always support the result of survey in Banisanta brothel. Although the distribution of age, education and religion is similar in both the brothels but entire sex workers in Phultala brothel was living in rental house as well as consuming electricity. More than four-fifth of them were from rural areas. Main occupation of the parents' family was mainly agriculture and day labour. The average income of the sex worker of Phultala brothel was about BDT 10,000 (US\$129) which is little bit higher than that of Banisanta.

\section{Drinking Water and Sanitation}

Table 2 shows the living condition of respondents relating to safe drinking water and sanitation. All the dwellers of Banisanta brothel used to collect water from outside by paying money to collector because there was no tube-well inside the community. About $35 \%$ of the respondents used to think their drinking water was safe and $31 \%$ of them thought the drinking water was unsafe. More than half (53\%) of the respondents were using hanging latrine and $29 \%$ of them were using pit latrine without water seal. Around half of the respondents $(47 \%)$ used to think the latrine they were using was dirty and $33 \%$ of them had opposite opinion. Forty-three percent of them used to think that the latrine was unhygienic.

Although the situation relating to safe drinking water and sanitation was not good said by the respondents, $63 \%$ of them were not suffering from diarrhoea, dysentery, typhoid, jaundice, etc during last one year. Only $4 \%$ of the respondents had dysentery and the highest $37 \%$ had diarrhoea.

The situation was observed much better in Phultala brothel. They were using community latrine constructed inside the brothel which is clean, not bad smelling like Banisanta brothel. They also use deep tube-well water for drinking and washing which is installed inside the brothel. Many of them used to understand that human excreta concerns with diarrhoea and dysentery and no one claimed suffering from diarrhoea, dysentery, typhoid, jaundice, etc during last one year. 
Table 2. Living condition related to safe drinking water and sanitation

\begin{tabular}{|c|c|c|}
\hline Variables & Frequency & Percentage \\
\hline \multicolumn{3}{|l|}{ Drinking water } \\
\hline Community/Private tube-well & 0 & 0 \\
\hline Buy from out side & 51 & 100 \\
\hline \multicolumn{3}{|c|}{ Safety of drinking water } \\
\hline Unsafe & 16 & 31 \\
\hline In between & 17 & 33 \\
\hline Safe & 18 & 35 \\
\hline \multicolumn{3}{|l|}{ Types of latrine } \\
\hline Hanging latrine & 27 & 53 \\
\hline Pit latrine (Not water sealed) & 15 & 29 \\
\hline Pit latrine (Water sealed) & 8 & 16 \\
\hline Others & 1 & 2 \\
\hline \multicolumn{3}{|l|}{ Cleanliness of latrine } \\
\hline Not dirty & 17 & 33 \\
\hline In between & 10 & 20 \\
\hline Dirty & 24 & 47 \\
\hline \multicolumn{3}{|l|}{ Condition of latrine } \\
\hline Unhygienic & 22 & 43 \\
\hline In between & 9 & 18 \\
\hline Hygienic & 20 & 39 \\
\hline \multicolumn{3}{|c|}{ Suffer from common diseases during last one year } \\
\hline Yes & 19 & 37 \\
\hline No & 32 & 63 \\
\hline \multicolumn{3}{|l|}{ Types of diseases } \\
\hline Diarrhoea & 17 & 33 \\
\hline Dysentery & 2 & 4 \\
\hline Jaundice & 3 & 6 \\
\hline
\end{tabular}

\section{Causes of Entering Sex Work}

Fifty one percent of the respondents entered to the sex work willingly. Some other reasons were identified such as sold $(27 \%)$, forced $(18 \%)$ and cheated $(2 \%)$. Those who entered willingly responded low family income (33\%) as the main cause and other $2 \%$ mentioned divorce and the remaining $16 \%$ could not identify the causes of entry. About $51 \%$ of them had experience with other labour market before sex work. The main cause of leaving the previous job were harassment (24\%) poor income coupled with physical abuse, working condition $(12 \%)$, personal or family based reasons $(12 \%)$ and migration (4\%) (Table 3$)$.

Table 3. Causes of entering sex work

\begin{tabular}{ccc}
\hline Variables & Frequency & Percentage \\
\hline Entering into sex work & & \\
\hline Myself & 26 & 51 \\
Forced & 9 & 18 \\
Sold & 14 & 27 \\
Cheated & 1 & 2 \\
No reply & 1 & 2 \\
\hline If the answer 'myself' & & \\
\hline Low family income & 17 & 33 \\
Divorce & 1 & 2 \\
Others & 8 & 16 \\
\hline Job before sex work & & \\
\hline Yes & 26 & 51 \\
No & 25 & \\
\hline Reason of leaving the job & & 12 \\
\hline Working conditions & 6 & 12 \\
Personal or family based reasons & 6 & 4 \\
Migration & 2 & 24 \\
Harassment & 12 &
\end{tabular}

FGD in Phultala brothel revealed very similar story to enter sex work. Some of them entered the job after being harassment, sold and cheated. Many of them started the job willingly to support their parent's family living in rural areas.

\section{Knowledge and Attitude on STI/STD}

About $84 \%$ of the respondents had idea about STI/STD and $78 \%$ had never suffered from the STDs. They were mainly suffering from headache $(41 \%)$, fever $(35 \%)$ and weakness $(24 \%)$. More than three-fourth $(76 \%)$ of the respondents were taking medicine, or used to go to the hospital when they become ill and about $94 \%$ of them meet peer educator. The peer educators used to discuss about using condoms $(76 \%)$, health related issues $(63 \%)$ and counselling and testing HIV (61\%).

Almost similar situation was found in Phultala brothel. They used to go drop-in-centre (DIC) and receive clinical, recreational services, health education, and also counselling. They also mention peer educator always used to discuss them different issues like counselling and testing (HIV), health related issues, use of condoms and others.

Table 4. Knowledge and attitude of the respondents on STI/STD

\begin{tabular}{ccc}
\hline Variables & Frequency & Percentage \\
\hline Idea about STI/STD & & \\
\hline Yes & 43 & 84 \\
No & 8 & 16 \\
\hline Ever suffered from STD & & \\
\hline Yes & 11 & 22 \\
No & 40 & 78 \\
\hline Types of diseases usually suffered & \\
\hline Fever & 18 & 35 \\
Weakness & 12 & 24 \\
Headache & 21 & 41 \\
\hline Peer educator (PE) meeting & & \\
\hline Yes & 48 & 64 \\
No & 3 & 61 \\
\hline Usual discussion with PE (Multiple response) & 63 \\
\hline Counselling and testing (HIV) & 31 & 76 \\
Health related issues & 32 & \\
Use of condoms & 39 & 24 \\
\hline Medicine and medical support & & \\
\hline Yes & 39 & \\
No & 12 & \\
\hline
\end{tabular}

\section{Discussion}

There were many reasons involved motivating women to adopt prostitution profession. There could be two different categories in this concern for taking initiatives of women into sex work, voluntarily and involuntarily (UNESCO, 2002). In India, it has been observed that sex work is largely involuntary but some women joined knowingly (Nag, 2006). 
Domestic responsibilities, economic crisis and lack household economy forced women to involve in prostitution (Wawer et al., 1996). Researches show that economic reasons become the main cause for women into sex work in India (Blanchard et al., 2005). Women who chose sex work for economic reasons belong to particular social, caste and class groups (Somaiya et al., 1990).

Majority of women in sex work are illiterates, belong to lower castes and are from poor economic backgrounds (Ramesh et al., 2008). Slum life is one of the most factors that promote prostitution (UNESCO, 2003). Prevalence of prostitution due to prevailing poverty, peer pressure and family neglect and the other major causes were illiteracy and family breakdown (Phoenix, 1999).

Migration from less developed areas to cities facilitates women for involvement into prostitution (DeZalduondo, 1999). Researches in Russia indicate that lack of employment opportunities are the major reason of women involvement into prostitution (Aral et al., 2003). The poverty faced by the women in Africa has led them for taking decision to sell sex in exchange for money and favours in order to support their children (Cabrera, 1998). In China, lack of money and economic necessities are the reasons of joining women sex work (Hong \& Li, 2008). In USA, domestic violence leads women getting start into sex work. Interpersonal network influence and adult peer association pay its role of women involvement into prostitution (Dalla, 2001). Coercion, threats and deception by others, in Vietnam, were the major factors of women joining sex work (Busza, 2004).

Childhood sexual abuse, parents' clashes and running away from the house are the reasons to give way participation of women into prostitution (Simons \& Whitbeck, 1991). A study shows that illiteracy, failure of family support and lack of ability to fulfill their basic needs of the family or children, were key factors for adopting prostitution (Chattopadhyay et al., 1994). In view of the prostitution issue, lack of employment opportunities in rural areas, many girls go to work and are trafficked to brothels in India (Ghimire, 1994 p. 66).

Tahmina \& Moral (2004) showed in their study that most of the brothel-based prostitutes in Bangladesh do not accept prostitution by choice rather they are forced - a substantial number of girls are abducted, kidnapped or brought by cheating, and then sold to brothels every year. In Bangladesh, a girl after abduction is generally sold to different brokers, moving from one hand to another in many ways for several times, when she is finally sold to a sardarni (a senior prostitute/madam) of the brothel. At the beginning, a sold girl is kept starved, beaten up and gang-raped to suppress her resistance so that she is forced to take clients. She is further tortured by brutal beating and drug administering, and is being brought to the concerned authorities to manage a license for her to be a prostitute. For this entire exercise, the authorities are allegedly bribed. After a period, a prostituted girl intending to come out of the vicious trap of the brothel finds all its ways blocked, though she breaks up the bondage of sardarni.

In a study with 48 female prostitutes from Mumbai, India, it was identified that majority of the prostitutes were sold into prostitution by family members or acquaintances (Karandikar et al., 2011). Studies conducted in Bangladesh have found out that cheating of male and female brokers and deception by relatives, husband or stepmother as significant factors that are mostly instrumental to make the women and girls involved into prostitution (Rahman, 2001). A number of researchers across the world have primarily identified poverty or financial crisis along with unemployment and (or) underemployment as the root causes for prostitution (Monroe, 2005).

\section{Conclusions}

Women started sex work after being cheated, sold to the brothel and were forced. More than half had experiences of other job before sex work but had to leave for physical torture or sexual harassment. Although majority of them who started sex work willingly due to low family income didn't like the profession anymore. They were looking for opportunities to start new life leaving their existing profession. A change in attitude and behavior of us is necessary to receive them into normal social life.

\section{Acknowledgements}

The research was supported by Md. Asaduzzaman, Program Manager, ASHCVP Project, CSS and Mohammad Abdul Baten, Program Manager, HIV/AIDS Project, CSS. We are also thankful to Dr. David Khan, Director, Health, CSS for logistics and other arrangement in Banisanta and to Dr. Md. Saiful Imam, Director, Health, CSS for the similar support in Phultala brothel.

\section{REFERENCES}

Alam, M. F., \& Das, T. K. (2014). Experiencing vulnerability, abuse and deception: Why women in Sylhet city of Bangladesh enter into prostitution. International Journal of Social Work and Human Services Practice, 2(3), 66-75.

Alam, R. (2005). Brothel-based and floating sex workers in Bangladesh: Living condition and socio-economic status. Available at:

http://www.childtrafficking.com/Docs/tdh_2005_brothel_based_fl oating_sex_workers_bangladesh_10.pdf

Aral, S. O., Lawrence, J. S. S., Tikhonova, L., Safarova, E., Parker, K. A., \& Shakarishvili, A. (2003). The social organization of commercial sex work in Moscow, Russia. Sexually Transmitted Disease, 30(1), 39-45.

ATSEC (1998). Available at:

http://atsec.tripod.com/atsecbangladeshchapter/ind ex.htm 
Blanchard, J. F., O'Neil, J., Ramesh, B. M., Bhattarcharjee, P., Orchard, T., \& Moses, S. (2005). Understanding the social and cultural contexts of female sex workers in Karnataka, India: Implications for prevention of HIV infection. Journal of Infectious Diseases, 191(1), 139-146.

Blanchard, J., Khan, A., \& Bokhari, A. (2008). Variations in the population size, distribution and client volume among female sex workers in seven cities of Pakistan. Sexually Transmitted Infection, 84(2), 24-27, doi:10.1136/sti.2008. 033167.

Busza, J. (2004). Sex work and migration: The dangers of over simplification: A case study of Vietnamese women in Cambodia. Health Human Rights, 7(2), 231-249.

Cabrera, F. O. (1998). Prostitution and poverty in Santafe de Bogota. Profamilia, 16, 53-56.

Chattopadhyay, M., Bandyopadhyay, S., \& Duttagupta, C. (1994). Biosocial factors influencing women to become prostitutes in India. Social Biology, 41, 252-259.

Dalla, R. (2001). Et tu brute? An analysis of prostitutes: interpersonal support networks. Journal of Family Issues, 22(8), 1066-1085.

Dandona, R., Dandona, L., Kumar, G. A., Gutierrez, J. P., McPherson, S., \& Samuels, F. (2006). Demography and sex work characteristics of female sex workers in India. BMC International Health of the Human Rights, 6(5), doi:10.1186/1472-698X-6-5.

DeZalduondo, B. O. (1999). Prostitution viewed cross-culturally: toward recontextualizing sex work in AIDS intervention research. Journal of Sexual Research, 28, 223.

Dickson, S. (2004). Sex in the City: Mapping commercial sex across London. The POPPY Project, London.

ECPAT (2005). ECPAT database. Available at: http://www.ecpat.net

FBI (2009, 2010). Uniform crime report: Available at: http://www.fbi.gov

Frederick, J. (2000). Fallen angels: the sex workers of South Asia. Luster press, New Delhi.

Ghimire, D. (1994). Girl trafficking in Nepal - a situation analysis red light traffic (pp. 66). Kathmandu: ABC/Nepal.

Gomes, R. G. (2014). Building capacity and empowering communities (BCEC) Project. BASD. Available at: http://www.basdbd.org/pdf/1st_year_3rd_Qrt_Newsletter.pdf

Hong, Y., \& Li, X. (2008). Behavioral studies of female sex workers in China: A literature review and recommendation for future research". AIDS Behaviour, 12(4), 623-636.

Journal, 1(2), 33-48.

Karandikar, S., Gezinski, L. B., \& Meshelemiah, J. C. A. (2011). A qualitative examination of women involved in prostitution in Mumbai, India: The role of family and acquaintances. International Social Work, doi: 10.1177/0020872811425804.
Karim, S. (2004). Exploring the household compositions of female sex-workers in brothels of Daulatdia: A case study. BRAC University

Khan, A. A., \& Khan, A. (2005).The HIV epidemic in Pakistan. Journal of Pakistan Medical Association.

Monroe, J. (2005). Women in street prostitution: The result of poverty and the brunt of inequity. Journal of Poverty, 9(3), 69-88, doi: 10.1300/J134v09n03_04.

Nag, M. (2006). "Sex workers of India: Diversity in practice of prostitution and ways of life". Allied Publishers Private Limited, New Delhi, India.

Naqvi, L., \& Jerar. (2005). Prostitution, human trafficking thrives as a lucrative immorality. Available at: http://202.221.217.59/print/features/life2005/f120050209a1.htm

Phoenix, J. (1999). Making sense of prostitution. St. Martin's. New York: Press, Inc.

Rahman, M. H. (2001). Social work and social development. Dhaka: Gatidhara.

Ramesh, B. M, Moses, S., Washington, R., Isac, S., Mohapatra B., \& Mahagaonkar, S. B. (2008). Determinants of HIV prevalence among female sex workers in four south Indian states: analysis of cross-sectional surveys in twenty-three districts. AIDS, 22(5), $35-44$.

Routledge, R. W. (2000). Sex for sale: Prostitution, pornography, and the sex industry.

SWNB (2001). Profile of member organization. Available at: http://www.swnob.com/?page_id=27

Simons, R. L., \& Whitbeck, L. B. (1991). Sexual abuse as a precursor to prostitution and victimization among adolescent and adult homeless women. Journal of Family Issues, 12, 361- 379.

Somaiya, P. A., Awate, R. V., \& Bhore, P. D. (1990). Socio-psychological study of the prostitutes. Indian Journal of Public Health, 34, 93-97.

Tahmina, Q. A., \& Moral, S. (2004). Sex-workers in Bangladesh, Livelihood: At what price? Shed: Bangladesh.

UNESCO (2002). A cultural approach to HIV/AIDS prevention and care: Towards a handbook for India. Studies and Reports Special Series, New Delhi,16.

UNESCO (2003). Sex work and HIV/AIDS. Geneva: Joint United Nations Programme on HIV/AIDS.

Wawer, M. J., Podhisita, C., Kanungsukkasem, U., Pramualratana, A., \& McNamara R (1996). Origins and working conditions of female sex workers in urban Thailand: Consequences of social context for HIV transmission. Social Science of Medicine, 42(3), 453-462.

Wood. (2001). Making Sense of Prostitution, St. Martin's Press, Inc., New York.

WB (2006). HIV AIDS in Pakistan, Islamabad. 